\title{
Developmental Regulation of Segment-Specific Cholinergic Receptors on Retzius Neurons in the Medicinal Leech
}

\author{
William B. Kristan, Jr., Kathleen A. French, and Lidia Szczupak \\ Department of Biology, University of California at San Diego, La Jolla, California 92093
}

\begin{abstract}
Retzius (Rz) neurons in the midbody ganglia of medicinal leeches responded to ACh, applied to their somata, in a manner that depended upon the neuron's segmental location: $R z$ neurons in ganglia from midbody segments 5 and 6 $[R z(5,6)]$ hyperpolarized, whereas $R z$ neurons from all other segments $[\operatorname{Rz}(X)]$ depolarized. Midbody segments 5 and 6 are notable because they contain the male and female reproductive organs. Both types of $\mathrm{Rz}$ neurons responded to $A C h$ in a complex way, but the initial phase of each response appeared to be nicotinic because nicotinic agonists evoked the responses and nicotinic antagonists blocked them. The reversal potentials of the responses and the effects of changing the internal and external $\mathrm{Cl}^{-}$concentration indicated that the hyperpolarizing response of $R z(5,6)$ neurons depended upon $\mathrm{Cl}^{-}$whereas the depolarizing response of $\mathrm{Rz}(X)$ neurons did not. The segmentally characteristic responses of $\mathbf{R z}$ neurons arose during embryonic development. Removing the reproductive ducts [the peripheral targets of $\operatorname{Rz}(5,6)]$ early in embryogenesis caused the $R z(5,6)$ neurons to depolarize in response to $\mathrm{ACh}$ rather than to hyperpolarize. This result indicates that development of the characteristic response of $\mathbf{R z}$ neurons to ACh is strongly influenced by interactions between the neurons and their appropriate target tissues.
\end{abstract}

[Key words: leech, ACh receptors, development, embryogenesis, nicotinic, d-tubocurarine, $\alpha$-bungarotoxin]

The differentiated phenotype of a neuron is determined by both intrinsic and extrinsic mechanisms. Extrinsic factors include contact with other cells or with the extracellular matrix, and the secretion of hormones or soluble growth factors by the surrounding tissue (Shankland and Macagno, 1992). These interactions may profoundly shape the developmental fate of cells. For example, interactions among ectodermal cells in embryonic insects determine which cells become neurons and which become epithelial cells (Doe and Goodman, 1985), and the fate of neural crest cells is influenced by interactions that occur along the path followed by the cells as they migrate away from the CNS (LeDouarin, 1980; Perris and Bronner-Fraser, 1989). In

\footnotetext{
Received July 20, 1992; revised Oct. 9, 1992; accepted Oct. 19, 1992.

We are grateful for the help of many of our colleagues, particularly Darwin Berg and Pierre Drapeau, who were consulted at several points in the progress of this work and also made useful suggestions about the manuscript. This work was supported by research grants from the NIH (NS25916) and March of Dimes to W.B.K. and K.A.F., and by a Fundacion Antorchas fellowship to L.S.

Correspondence should be addressed to William B. Kristan, Jr., Department of Biology 0322, University of California at San Diego, La Jolla, CA 92093-0322. Copyright (@) 1993 Society for Neuroscience $0270-6474 / 93 / 131577-11 \$ 05.00 / 0$
}

addition, cellular interactions shape specific features of differcntiating ncurons. For instance, the axonal branching pattern of many neurons develops as their growth cones are attracted to or repelled by other cells or by molecules in the extracellular matrix (Letourneau et al., 1991); the neurotransmitter produced by some neurons depends upon what target they innervate, both in vivo (Schotzinger and Landis, 1990) and in vitro (Patterson and Chun, 1977; Potter et al., 1986); and developing sensory neurons in frogs may acquire the information that allows them to establish appropriate synapses within the spinal cord as a result of contact with their peripheral targets, that is, skin or muscle (Smith and Frank, 1987).

Like these vertebrate neurons, Retzius $(\mathrm{Rz})$ neurons - a pair of identified neurons in each midbody ganglion (M1-M21) of the leech-possess several distinctive morphological and physiological features that are determined by their external environment during development. There are two major classes of $\mathrm{Rz}$ neurons, each of which has a distinctive peripheral target. $\mathrm{Rz}$ neurons in the segments containing the reproductive ducts (midbody segments 5 and 6 ) exclusively innervate the male and female reproductive ducts, whereas $\mathrm{Rz}$ neurons in the other 19 ("standard") midbody segments innervate the muscles and glands of the body wall (Lent, 1973; Glover and Mason, 1986; Jellies et al., 1987). Morphologically, Rz neurons in M5 and M6 $[R z(5,6)$ neurons] have smaller somata and fewer processes within the central neuropil than do $\mathrm{Rz}$ neurons in standard midbody ganglia $[\mathrm{Rz}(\mathrm{X})] . \mathrm{Rz}(5,6)$ neurons extend a profusely branched axonal arbor among the muscles of the reproductive ducts, and they lack axons both in nerves that branch among the muscles of the body wall and in the interganglionic connectives. In contrast, $\operatorname{Rz}(\mathrm{X})$ neurons branch extensively in the body wall and normally do not innervate reproductive ducts, even though $\mathrm{Rz}(4)$ and $\mathrm{Rz}(7)$ establish secondary peripheral fields of innervation among the muscles and body wall in midbody segments 5 and 6 (Loer and Kristan, 1989a). In addition, $\mathrm{Rz}(5,6)$ neurons fail to respond to, or are even inhibited by, two sources of synaptic input that strongly depolarize $\mathrm{Rz}(\mathrm{X})$ neurons (Wittenberg et al., 1990).

The presence of the reproductive ducts is crucial for the development of the $\mathrm{Rz}(5,6)$ phenotype, because after embryonic reproductive ducts were removed about one-third of the way through embryogenesis, many morphological and physiological features of the Rz neurons in M5 and M6 were more like $\mathrm{R} 7(\mathrm{X})$ neurons than like $\mathrm{Rz}(5,6)$ (Loer et al., 1987; Loer and Kristan, 1989c). In addition, when embryonic reproductive ducts were transplanted into nonreproductive segments, the local Rz neurons innervated them and changed their developmental program to some extent (Loer and Kristan, 1989b). This switch to the $\mathrm{Rz}(5,6)$ phenotype was more complete when the reproductive 
ducts were present in the inappropriate segments from early stages of development, either by developmental anomaly (Macagno et al., 1986) or by experimental design (Gleizer and Stent, 1990). At the time when $\operatorname{Rz}(5,6)$ neurons first begin to diverge morphologically from the $\mathrm{Rz}(\mathrm{X})$ pattern, their growth cones are in intimate contact with mesenchymal cells of the reproductive ducts, suggesting that these precursors of duct muscles provide the inductive cues that change the fate of these $\mathrm{Rz}$ neurons (French and Kristan, 1992; French et al., 1992). From these results, we have hypothesized that the features of the $\mathrm{Rz}(\mathrm{X})$ neurons comprise the "default" developmental program of $\mathrm{Rz}$ neurons, and that contact with the primordial reproductive ducts modifies the program to generate the $\operatorname{Rz}(5,6)$ phenotype.

The two $\mathrm{Rz}$ phenotypes appeared to be sufficiently different that it seemed possible that they would each possess a unique array of membrane receptor molecules as well. To determine whether $\operatorname{Rz}(5,6)$ and $\operatorname{Rz}(\mathrm{X})$ neurons differed in molecular, as well as in morphological and synaptic features, we tested the effects of several neurotransmitters on $\mathrm{Rz}(\mathrm{X})$ and $\mathrm{Rz}(5,6)$ neurons. Earlier work indicated that $\mathrm{Rz}$ neurons are excited by glutamate (James et al., 1980; Mat Jais et al., 1983) and by ACh (Sargent et al., 1977; Gardner and Walker, 1983; Pellegrino and Simmoneau, 1984); they are inhibited by 5-HT and octopamine (Smith and Walker, 1975; Sunderland et al., 1980; Pellegrino and Simmoneau, 1984) and by the glycine antagonist strychnine (Walker and Smith, 1973). GABA, the inhibitory transmitter onto leech muscles and motor neurons (Cline, 1986), had not been reported to affect $\mathrm{Rz}$ neurons. However, none of the previous studies had specified the segmental location of the ganglia tested, and in most previous studies the neurotransmitters were applied via the saline bathing an isolated ganglion, rather than focally onto a single soma.

Because we were primarily interested in cell specificity, it was important to keep track of the segmental origin of each ganglion tested. To reduce the possibility that responses to ACh were mediated via another neuron that synapsed with the $\mathrm{Rz}$ neuron being studied, each substance was pressure-ejected directly onto the $\mathrm{Rz}$ soma while the ganglion was bathed in a saline designed to block chemical synaptic transmission (Nicholls and Baylor, 1968; Nicholls and Purves, 1970). In the present work, six substances were tested, and only ACh affected $\mathrm{Rz}(5,6)$ differently from $\mathrm{Rz}(\mathrm{X})$. Further experiments established that the receptors mediating the two responses to ACh are located on the soma and that the responses are mediated by two different kinds of nicotinic receptors.

A preliminary account of this work has been published previously (Kristan and French, 1988).

\section{Materials and Methods}

Preparations. Medicinal leeches, Hirudo medicinalis, weighing 2-5 gm, were obtained from a commercial supplier and maintained at $15^{\circ} \mathrm{C}$ in artificial pond water. The animals were not fed for at least 1 month prior to dissection. Individual ganglia were dissected and pinned, ventral side up, to Sylgard (Dow Corning) in plastic Petri dishes $(35 \mathrm{~mm}$ diameter) filled with normal leech saline (see Solutions and materials). The sheath covering the ganglion was dissected away, leaving all the neuronal cell bodies on the ventral surface exposed to the bathing fluid. For most experiments, a multibarreled electrode containing the stimulating substances and an intracellular recording electrode were manipulated into place on opposite sides of the $\mathrm{Rz}$ ncuron within the ganglion. For the remaining experiments, the somata of individual $\mathrm{Rz}$ neurons were plucked from their primary axon and cultured individually (see below). Saline was perfused across the preparation to carry the stimulating substance over the cell's surface and to wash it away rapidly.
Embryos were obtained from a breeding colony maintained in the laboratory, and staged according to criteria established for development at $20^{\circ} \mathrm{C}$ (Fernandez and Stent, 1982). Ganglia were dissected from embryos and pinned onto the surface of a glass microscope slide coated with Sylgard (Dow Corning). The slides were mounted on the immobilized stage of a Zeiss Standard microscope and viewed with differential interference (Nomarski) optics, and the electrodes were controlled with Narishige hydraulic manipulators mounted on the stage.

Solutions and materials. The composition of the normal leech saline was (in $\mathrm{mM}$ ) $\mathrm{NaCl}, 115 ; \mathrm{KCl}, 4 ; \mathrm{CaCl}_{2}, 1.8 ; \mathrm{MgCl}_{2}, 1.5$; Tris maleate, 4.6, Tris base, 5.4 ; and glucose, $10 ; \mathrm{pH} 7.4$. High- $\mathrm{Mg}^{2+}$ saline, used to block synaptic transmission (Nicholls and Baylor, 1968; Nicholls and Purves, 1970), contained $20 \mathrm{mM} \mathrm{MgCl}_{2}$ and $1 \mathrm{~mm} \mathrm{CaCl}$, maintaining normal osmolarity by decreasing the $\mathrm{NaCl}$ concentration. Solutions with lowered concentrations of $\mathrm{Cl}^{-}$were made by substituting an osmotically equivalent amount of $\mathrm{Na}_{2} \mathrm{SO}_{4}$ for $\mathrm{NaCl}$. The following chemicals were used: serotonin, dopamine (DA), octopamine, strychnine, $\gamma$-aminobutyric acid (GABA), glutamic acid, acetylcholine chloride (ACh), nicotine (hemisulfate salt), $d$-tubocurarine chloride, and $\alpha$-bungarotoxin ( $\alpha$-Bgt); all were obtained from Sigma. The purity of the $\alpha$-bungarotoxin was not tested, but purified toxin obtained from Darwin Berg (UC San Diego Biology Dept.) produced identical results, so it is unlikely that our results were due to contaminants in the commercial toxin.

Cell culture. $\mathrm{Rz}$ neurons were isolated and cultured following the procedures described by Dietzel et al. (1986). Desheathed ganglia were exposed to $2 \mathrm{mg} / \mathrm{ml}$ collagenase/dispase (Boehringer Mannheim) for 1 hr at $22^{\circ} \mathrm{C}$, and identified $\mathrm{Rz}$ neurons were removed by suction into a micropipette (tip diameter, $30-70 \mu \mathrm{m}$ ). The isolated cells were plated in concanavalin A-coated microwell plates (Nunc) containing Leibovitz-15 (L-15) medium supplemented with $2 \%$ heat-inactivated fetal bovine serum (HyClone Lab), $2 \mathrm{~mm}$ glutamine, $6 \mathrm{mg} / \mathrm{ml}$ glucose, and $0.1 \mathrm{mg} / \mathrm{ml}$ gentamicin sulfate (all from Sigma).

Recordings. During the electrophysiological recordings, the ganglia were continuously superfused with a saline containing high $\mathrm{Mg}^{2+}$ (see Solutions and materials) to avoid polysynaptic effects of the drugs applied onto the $\mathrm{Rz}$ cell soma. $\mathrm{Rz}$ neurons were impaled with microelectrodes pulled from thin-walled omega-dot glass (Frederick Haer). The microelectrodes were filled with $4 \mathrm{M}$ potassium acetate and had resistances of 20-40 M . Neurons were loaded with $\mathrm{Cl}^{-}$by filling the electrodes with $4 \mathrm{M} \mathrm{KCl}$ and passing hyperpolarizing currents $(2-4 \mathrm{nA})$ into the cells. The recordings were displayed on a Tektronix D11 storage oscilloscope and on a Gould-Brush 220 chart recorder. Most experiments wcre performed by impaling the cell with a single electrode, using a Getting model 5 amplifier. A bridge circuit was used for measuring the membrane potential through the same electrode used to inject current. For those experiments in which a more precise medsurement of the membrane potential of the cells was important during current passage, the neurons were impaled with two microelectrodes, one to measure changes in membrane potential and the other to apply current.

Application of substances onto the cell bodies of $R z$ neurons. Agonists were applied by pressure pulses to the back of a single- or multibarreled pipette (single tip diameter, approximately $10 \mu \mathrm{m}$ ) containing a solution of the agonist dissolved in the bathing solution. In the initial screen of neurotransmitters (Fig. 1), the pressure was applied to one barrel of a seven-barreled pipette, each filled with a different substance. At least one barrel always contained the same saline used to perfuse the preparation, as a control for mechanical effects of pressure ejection. Having found how much movement a soma could produce with no electrical consequence, saline-filled barrels were eliminated in later experiments. Multibarreled pipettes were also used to determine the dose-response curves (Fig. 2); in the remaining experiments, single-barreled pipettes were used. The tip diameters of the micropipettes were standardized by measuring their "bubble number" (Corey and Stevens, 1983) We used pipettes with bubble numbers from 9.0 to 9.2 . The ejection pipette was positioned using a micromanipulator with the tip 20-30 $\mu \mathrm{m}$ from the cell. The amplitude and duration of the pressure pulses were controlled by a Picospritzer II (General Valve Co.), and the pulses were applied under visual control through the microscope.

To estimate how much the solutions ejected from the pipette were diluted before reaching the soma of the $\mathrm{Rz}$ neurons, we measured the dcpolarization caused by pressure-ejecting several different concentrations of $\mathrm{K}^{+}$(as $\left.\mathrm{KCl}\right)$. Each resulting depolarization was compared to depolarizations observed when the cells were sequentially bathed in standard leech saline solutions containing different concentrations of $\mathrm{KCl}$. In these experiments, the neurons quickly reached a stable level 
A

$\operatorname{Rz}(4)$

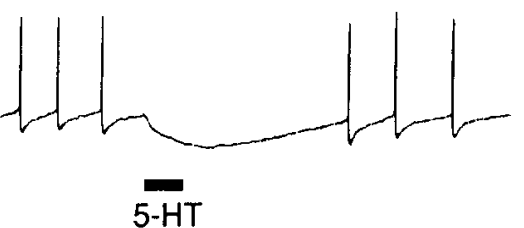

C
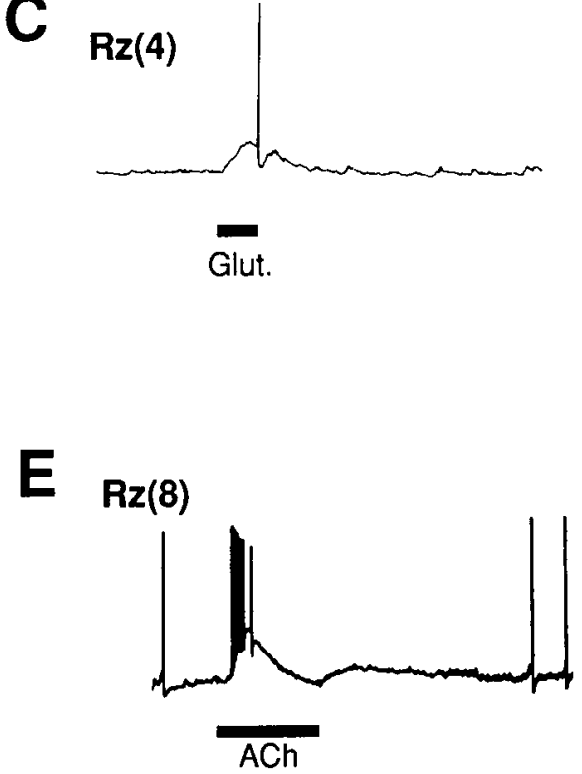

B $R z(5)$

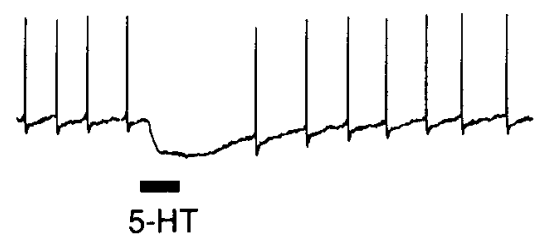

D

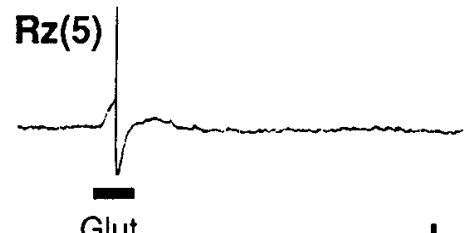

$20 \mathrm{mV}$

$\mathbf{F}$

$\mathrm{Rz}(6)$

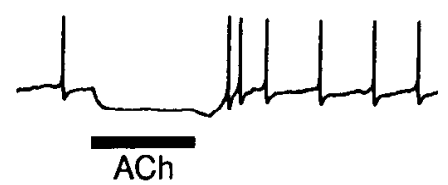

Figure 1. The effects of three transmitters on the membrane potential of standard and reproductive $\mathrm{Rz}$ neurons. $A$ and $B$, Hyperpolarizing responses of a standard $\mathrm{Rz}$ neuron, $\mathrm{Rz}(4)$, and a reproductive $\mathrm{Rz}$ neuron, $\mathrm{Rz}(5)$, to $5-\mathrm{HT}$ $\left(10^{-4} \mathrm{M}\right) . C$ and $D$, Depolarizing responses of the same neurons to glutamate $\left(10^{-4} \mathrm{M}\right) . E$, Depolarizing response of $\mathrm{Rz}(8)$, a typical $\mathrm{Rz}(\mathrm{X})$ neuron, to the application of ACh $\left(5 \times 10^{-4} \mathrm{M}\right)$. $F$, Hyperpolarizing responses of an $\mathrm{Rz}(6)$ neuron to the application of $\mathrm{ACh}$ $\left(5 \times 10^{-4} \mathrm{M}\right)$ The time and voltage calibrations apply to all recordings. In this and all subsequent figures, the substance was applied during the time indicated by the solid bar under the recording. of depolarization in response to high external $\mathrm{K}^{+}$, whether it was delivered via the pipette or via the bathing saline. In three such experiments, the $\mathrm{KCl}$ solution in the pipette had to be three to four times more concentrated than was $\mathrm{KCl}$ in the bathing solution in order to produce the same depolarization. We conclude, therefore, that the minimum concentration of transmitter substances reaching the neurons was about one-fourth the concentration in the pipette.

Relative size of $R z$ somata. Ganglia were viewed using differential interference contrast optics on a Zeiss Standard microscope, using a $40 \times$ water immersion objective and a $10 \times$ eyepiece with a calibrated reticle. The longest and shortest diameters of the $\mathrm{Rz}$ neuronal somata were measured at a resolution of $1 \mu \mathrm{m}$. (The minimum diameter of any
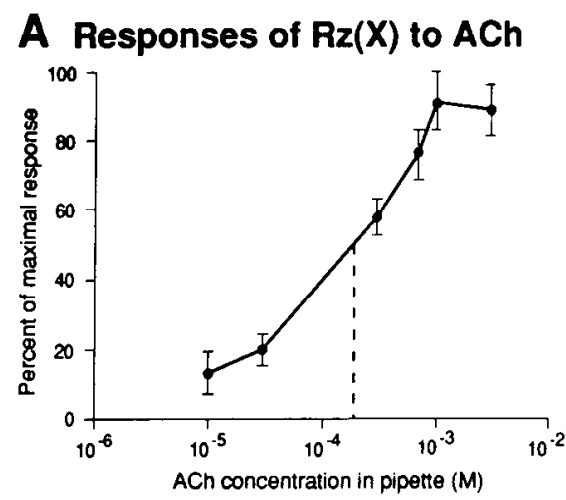

neuron in this study was $11 \mu \mathrm{m}$.) The area was calculated as $\pi r_{1} r_{2}$, the formula for the area of an oval with major and minor radii of $r_{1}$ and $r_{2}$. The relative size of $\mathrm{Rz}(5,6)$ was calculated by measuring the area of all the $\mathrm{Rz}$ neurons in midbody ganglia $4-7$, and then dividing the area of each $R z(5,6)$ soma by the average area of the four $R z(X)$ somata in ganglia 4 and 7.

\section{Results}

Responses of $R z$ neurons to neurotransmitters

Intracellular recordings were obtained from $\mathrm{Rz}$ neurons whose somata had been exposed by dissection of the overlying con-
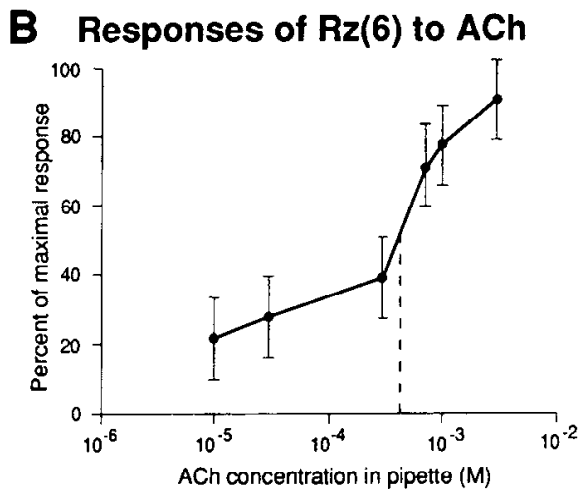

Figure 2. Responses of $\mathrm{Rz}$ neurons to different concentrations of $\mathrm{ACh}$. $A$, Depolarizing responses of standard $\mathrm{Rz}$ neurons. The magnitude of the response, normalized as a percentage of the maximum response for each $R \&$ neuron, was plotted as a function of $A C h$ concentration. The range of maximal responses was 4.4-18.4 mV. $B$, The magnitude of the hyperpolarizing responses of $\mathrm{Rz}(6)$, also normalized as a percentage of the maximal response for each $\mathrm{Rz}$ neuron, plotted as a function of $\mathrm{ACh}$ concentration. The range of maximal responses was -3.2 to $-7.1 \mathrm{mV}$. The ACh concentration that produced a half-maximal response is indicated by a dashed line on each graph. The values plotted are averages of 4-10 measurements. The error bars indicate the SEM for each point. 
Table 1. Responses of $R z$ neurons to substances applied onto their somata

\begin{tabular}{lll} 
& \multicolumn{2}{l}{ Cell type } \\
\cline { 2 - 3 } Substance & $\mathrm{Rz}(\mathrm{X})$ & $\mathrm{Rz}(6)$ \\
\hline 5-HT & $\mathrm{H}$ & $\mathrm{H}$ \\
Octopamine & $\mathrm{H}$ & $\mathrm{H}$ \\
Strychnine & $\mathrm{H}$ & $\mathrm{H}$ \\
GABA & $\mathrm{NR}$ & $\mathrm{NR}$ \\
Glutamate & $\mathrm{D}$ & $\mathrm{D}$ \\
ACh & $\mathrm{D}$ & $\mathrm{H}$
\end{tabular}

$\mathrm{Rz}(6)$ signifies the $\mathrm{Rz}$ neurons in midbody ganglion (MG) 6, and $\mathrm{Rz}(\mathrm{X})$ signifies $\mathrm{Rz}$ neurons from all midbody ganglia except MG 5 and 6; MG 3, 4, 7, 8, 12, 14, 15 , and 16 were tested. Responses of $\operatorname{Rz}(5)$ were similar to those of $\operatorname{Rz}(6)$, but weaker and sometimes mixed. $\mathrm{H}$ indicates a predominantly hyperpolarizing response in that $\mathrm{Rz}$ neuron type, $\mathrm{D}$ indicates a predominantly depolarizing response, and NR indicates no response. All substances except ACh were tested three times on each cell type, and the indicated response was obtained in all three trials. ACh produced a depolarizing response in 27 of $28 \mathrm{Rz}(\mathrm{X})$ neurons tested in these initial experiments, and it produced a hyperpolarizing response in $17 \mathrm{of} 18 \mathrm{Rz}(6)$ neurons tested. All substances were at a concentration of $10^{-4} \mathrm{M}$ in the pipette.

nective and glial coverings in isolated adult ganglia. These neurons had resting potentials ranging from -40 to $-50 \mathrm{mV}$. Substances were individually pressure-ejected from a seven-barreled pipette onto the exposed cell body of each $\mathrm{Rz}$ neuron while the ganglion was perfused by a stream of saline containing elevated
$\mathrm{Mg}^{+2}$. Six substances were used, including five neurotransmitters (5-HT, octopamine, GABA, glutamate, and ACh) and the glycinergic antagonist strychnine; they were applied at a concentration of $10^{-4} \mathrm{M}$ from the pipette barrels. The effects of three of these substances, typifying the full range of effects seen, are shown in Figure 1, and the effects of all the substances are summarized in Table 1. These data show that most of the substances had the same effects on both kinds of Rz cells: 5-HT, octopamine, and strychnine hyperpolarized all Rz neurons from their resting potential (Fig. $1 A, B$ ), glutamate depolarized all $\mathrm{Rz}$ neurons from rest (Fig. $1 C, D$ ), and GABA had no effect on $\mathrm{Rz}$ cell resting potentials. The only substance tested that differentially affected the two types of Rz neurons was ACh: it depolarized $\mathrm{Rz}(\mathrm{X})$ and hyperpolarized $\mathrm{Rz}(5,6)$ (Fig. $1 E, F)$.

\section{Dosage dependence of the ACh response}

We measured the magnitude of the maximal response of each $\mathrm{Rz}$ neuron in an isolated ganglion when different concentrations of $\mathrm{ACh}$ were ejected onto its soma. The minimal concentration of $\mathrm{ACh}$ in the pipette that produced a consistent response, either depolarizing in $\mathrm{Rz}(\mathrm{X})$ neurons or hyperpolarizing in $\mathrm{Rz}(5,6)$ neurons, was $10^{-5} \mathrm{M}$, and the maximal response was observed at an ACh concentration of about $5 \times 10^{-3} \mathrm{M}$ (Fig. 2). The midpoint of the response curve was $2 \times 10^{-4} \mathrm{M}$ for the depolarizing response (Fig. $2 A$ ) and $4 \times 10^{-4} \mathrm{M}$ for the hyperpolarizing response (Fig. $2 B$ ). These values suggest that the depolar-
A

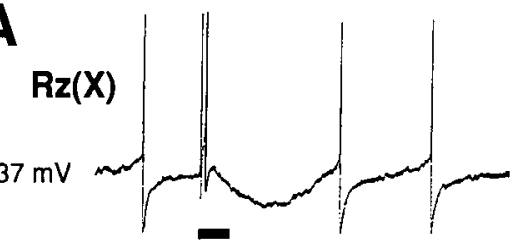

Figure 3. Responses of $\operatorname{Rz}(\mathrm{X})$ and $\mathrm{Rz}(5,6)$ neurons to $\mathrm{ACh}$. These are recordings of changes in membrane potential elicited by pressure ejection pulses of $\mathrm{ACh}\left(10^{-3} \mathrm{M}\right.$ in the micropipette) on an $\mathrm{Rz}(\mathrm{X})$ neuron $(A)$ and an $\mathrm{Rz}(6)$ neuron $(B)$ held initially at different membrane potentials. Current was passed into the neurons to bring them to the membrane potentials indicated to the left of each trace. $C$ and $D$, The relationship between the amplitude of the ACh responses and the initial membrane potential of the $R z$ neurons. Amplitudes of the changes in membrane potential of an $\mathrm{Rz}(\mathrm{X})$ neuron $(C)$ and an $\mathrm{Rz}(5,6)$ neuron $(D)$ elicited by the application of a 1 sec pulse of ACh are plotted against the initial holding potential for each neuron. For $\mathrm{Rz}(\mathrm{X})$, the amplitudes of both the initial depolarization and the later hyperpolarization are shown. The vertical arrow indicates the reversal potential of each response. The average reversal potential for the initial depolarizing response in $\mathrm{Rz}(\mathrm{X})$ was $-25 \pm 2 \mathrm{mV}$ ( $n$ $=10)$, and $-52 \pm 1 \mathrm{mV}(n=7)$ for the hyperpolarizing response. The average reversal potential for the hyperpolarization of $\mathrm{Rz}(5,6)$ was $-65 \pm 2 \mathrm{mV}$ ( $n$ $=6$ ).

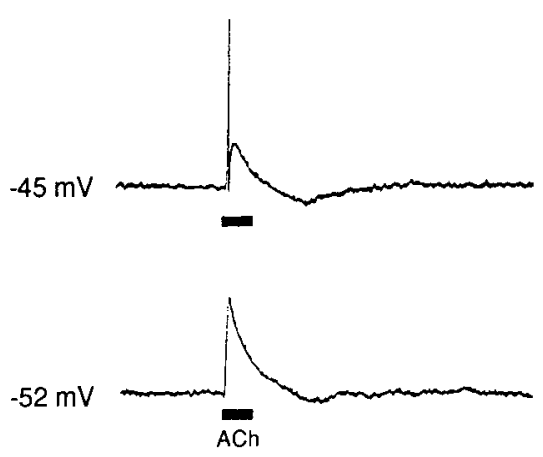

C
$\operatorname{Rz}(X)$ : Initial depol.

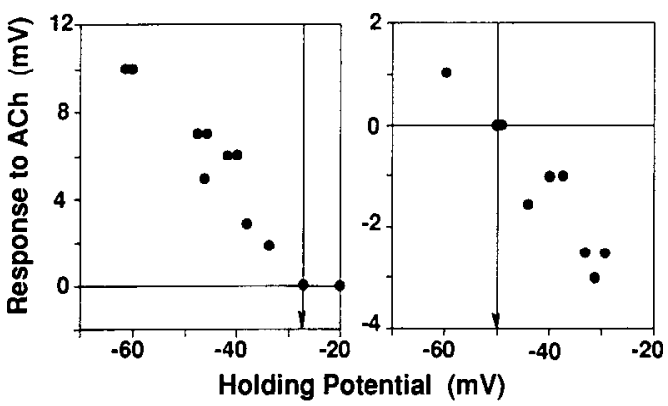

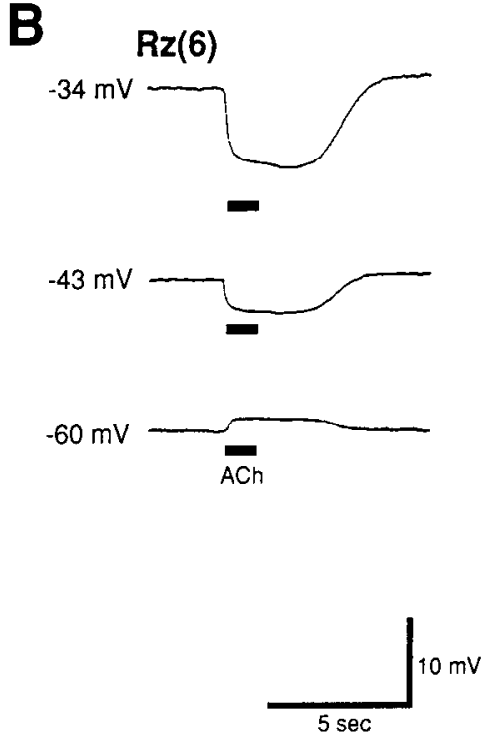

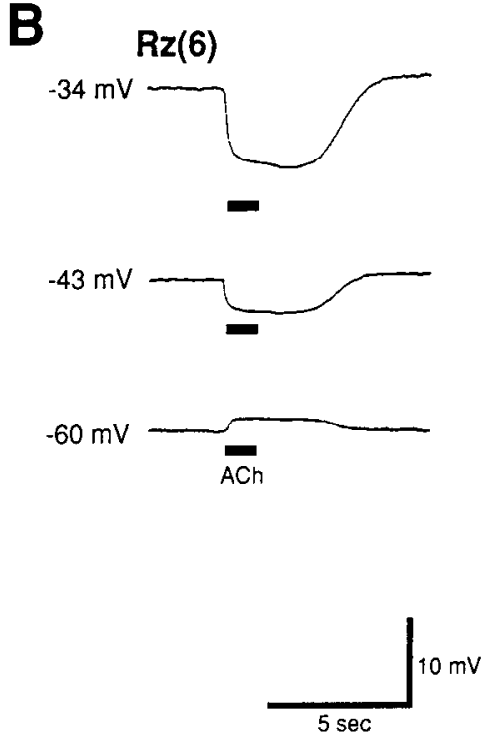

D $R z(6)$ : Initial hyperpol.

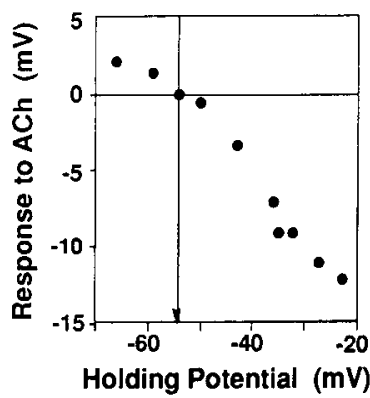


A

$\mathbf{R z}(\mathbf{X})$

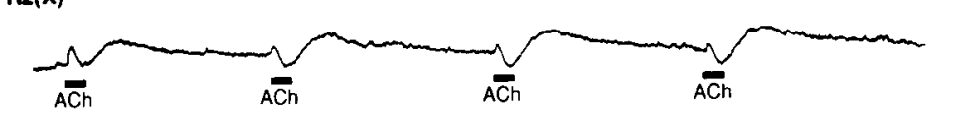

B

$\mathbf{R z}(6)$

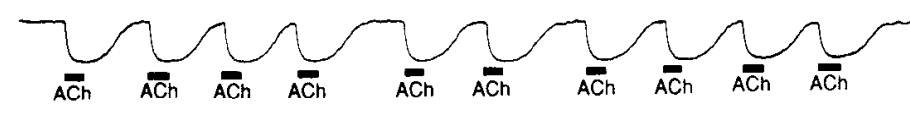

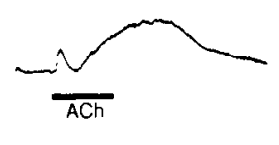
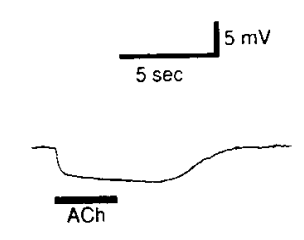

Figure 4. Responses of $\mathrm{Rz}$ neurons to multiple or prolonged pulses of $\mathrm{ACh}$. The traces are responses of $\mathrm{Rz}(\mathrm{X})(A)$ and $\operatorname{Rz}(6)(B)$ to the application of successive $1 \mathrm{sec}$ pulses of $\mathrm{ACh}\left(10^{-3} \mathrm{M}\right.$ in the pipette). The responses shown after the breaks at the right were elicited by $3 \mathrm{sec}$ pulses of ACh. In all cases, sufficient hyperpolarizing current was injected into the neurons to bring the membrane potential to $-55 \mathrm{mV}$ before the application of ACh. izing and hyperpolarizing receptors have similar affinities for $\mathrm{ACh}$, but the true value of $K_{D}$ for both receptors is probably lower for three reasons. First, any solution ejected from a micropipette into flowing saline is likely to be diluted by some amount before it reaches the surface of the soma (see Materials and Methods), so the true concentration of ACh seen by the receptors was probably one-fourth the concentration in the electrode. Second, when ganglia were bathed in eserine, the threshold concentration was reduced to below $10^{-6} \mathrm{M}$, so AChE activity appears to reduce significantly the ACh concentration presented to the receptors. Third, the amplitude of the responses, particularly at high concentrations of $\mathrm{ACh}$, may not have been varied linearly with ACh concentration, particularly at high concentrations, because the voltage was approaching the reversal potential. Future experiments, using voltage clamp to maintain a voltage far from the reversal potential, will rcsolve this issue. For present purposes, these results served to establish the useful range of ACh concentrations for further characterization of the responses.

\section{Distinctive features of $A C h$ responses}

The response of $R z(X)$ neurons to $A C h$. Pressure ejection of $\mathrm{ACh}$ onto $\mathrm{Rz}(\mathrm{X})$ neurons $(n=18)$ produced an initial depolarization that had a rise time of $0.2 \pm 0.02 \mathrm{sec}$ (mean \pm SEM). Its duration was short even if the ACh pulse was quite prolonged. This depolarization reversed at approximately $-25 \mathrm{mV}$ (Fig. $3 A, C$ ). In addition, these cells had a hyperpolarizing response that peaked after the initial depolarization (Fig. $3 A$ ), and a third phaseanother depolarization - that appeared most clearly when pulses of $\mathrm{ACh}$ were prolonged (Fig. $4 A$ ). The hyperpolarization was often difficult to detect between the two depolarizing responses, but could be accentuated by repeated short pulses of $\mathrm{ACh}$, which desensitized the initial depolarization. The hyperpolarizing response reversed at $-52 \mathrm{mV}$ (Fig. $3 C$ ). The delayed depolarization proved too variable to determine a clear reversal potential.

The response of $R z(5,6)$ neurons to $A C h$. Application of an ACh pulse onto the somata of $\operatorname{Rz}(5,6)$ neurons $(n=21)$ hyperpolarized the membrane below the resting potential (Fig. $3 B$ ). This response had a rise time of $0.66 \pm 0.04 \mathrm{sec}$ and lasted at least as long as the pulse was on (up to $10 \mathrm{sec}$ ). Unlike the initial depolarization in $\mathrm{Rz}(\mathrm{X})$, this hyperpolarization did not desensitize when ACh pulses were applied repeatedly or for prolonged times (Fig. 4B). During the response, the input resistance of the membrane (measured by superimposing short hyperpolarizing pulses) decreased by $40 \pm 5 \%(n=3)$, showing that ACh significantly increased the membrane conductance in $\mathrm{Rz}(5,6)$ neurons. This response reversed sign at approximately $-65 \mathrm{mV}$
(Fig. $3 D$ ), a value close to the expected chloride equilibrium potential in these cells (Pellegrino and Simmoneau, 1984; Ballanyi and Schlue, 1989; Drapeau et al., 1989). Two methods were used to test further whether the hyperpolarization was mediated by activation of a $\mathrm{Cl}^{-}$current. First, the response to ACh was recorded before and after cells were loaded with $\mathrm{Cl}^{-}$ by passing 10-30 sec pulses of hyperpolarizing current through an intracellular microelectrode filled with $4 \mathrm{M} \mathrm{KCl}$. This procedure either diminished the hyperpolarizing response to $\mathrm{ACh}$ in $\mathrm{Rz}(5,6)$ neurons that were held at their normal resting potential, or in some cases caused a depolarization (Fig. $5 A$ ). Second, the response to $\mathrm{ACh}$ was recorded before and after the extracellular $\mathrm{Cl}^{-}$was replaced by sulfate ions. This procedure also reversed the sign of the $A C h$ response in $\operatorname{Rz}(5,6)$ neurons (Fig. 5B). The depolarizing responses of $\mathrm{Rz}(\mathrm{X})$ neurons were not affected by similar manipulations of the intracellular or extracellular $\mathrm{Cl}^{-}$concentrations (data not shown).

\section{Effects of ACh on isolated somata}

Despite our efforts to direct ACh onto only the soma of each $\mathrm{Rz}$ neuron and to block chemical synaptic transmission with a high- $\mathrm{Mg}^{2+}$ saline, it seemed possible that some part of the response could be mediated by receptors on other neurons and transmitted, for instance, through electrical synapses with the Rz neurons. Therefore, we dissected somata of Rz neurons out of ganglia, placed them in culture for $1 \mathrm{~d}$, and then determined their responses to $\mathrm{ACh}$ as previously. The resting potentials of these neurons were comparable to those of $\mathrm{Rz}$ neurons in intact ganglia, and they generated action potentials of similar amplitude and duration. The initial responses of these isolated somata to $\mathrm{ACh}$ were essentially the same as the initial responses of intact neurons: $\mathrm{Rz}(\mathrm{X})$ neurons depolarized (Fig. 6.4) and $\mathrm{Rz}(5,6)$ neurons hyperpolarized (Fig. $6 B$ ). The subsequent responses of the isolated $\mathrm{Rz}(\mathrm{X})$ somata, however, were different from the normal $\mathrm{Rz}(\mathrm{X})$ responses in two ways. First, there was no evidence of the late depolarization, suggesting that this response may be mediated by receptors on processes that were removed when the cells were cultured, or by receptors on neurons electrotonically connected to the $\mathrm{Rz}(\mathrm{X})$ neurons in the intact ganglion. Second, the hyperpolarizing response was more pronounced in these cells than in intact $\mathrm{Rz}(\mathrm{X})$ neurons (compare Fig. $6 A$ to Figs. $3 A, 4 A$ ). Part of this enhancement is probably due to the absence of the late depolarization. In addition, the hyperpolarization may have been larger because the input resistance of the $\mathrm{Rz}(\mathrm{X})$ neurons was higher in culture $(34 \pm 3 \mathrm{M} \Omega$, $n=4)$ than in the ganglion ( $13 \pm 2 \mathrm{M} \Omega, n=4)$. In both cases, input resistances were measured by passing $1 \mathrm{nA}$ of hyperpo- 
A Before $\mathrm{Cl}^{-}$loading

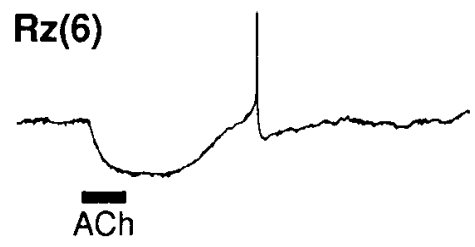

Figure 5. Effects of varying the intracellular and extracellular concentrations of $\mathrm{Cl}^{-}$on the ACh responses of $\mathrm{Rz}(6)$ neurons. $A$, Responses of the same $\mathrm{Rz}(6)$ neuron to the application of $\mathrm{ACh}$ $\left(10^{-3} \mathrm{M}\right.$ in the pipette) before and after loading the neuron with $\mathrm{Cl}^{-}$by passing hyperpolarizing current $(2 \mathrm{nA})$ into the cell for $130 \mathrm{sec} . B$, Responses of another $\mathrm{Rz}(6)$ neuron to $\mathrm{ACh}\left(10^{-3} \mathrm{M}\right.$ in the pipette) in standard saline and in saline in which all the $\mathrm{Cl}^{-}$had been replaced by sulfate. The extracellular $\mathrm{Cl}^{-}$concentration $\left.\left(\mathrm{CCl}^{-}\right]_{o}\right)$ in the bathing solution is indicated for each trace.
B $\left[\mathrm{Cl}^{-}\right]_{0}=130 \mathrm{mM}$

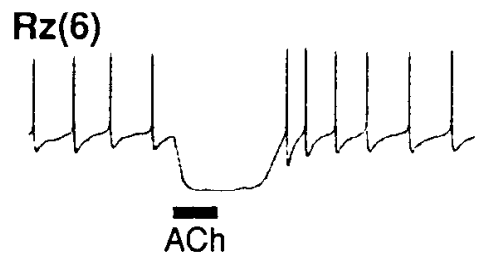

After $\mathrm{Cl}^{-}$loading

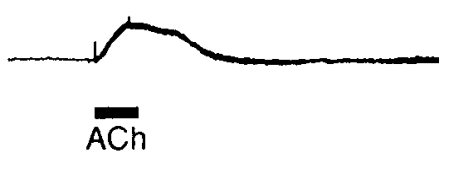

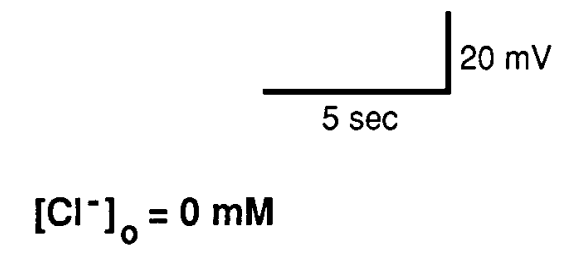

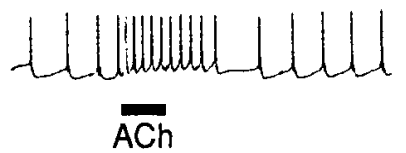

larizing current. The larger resistance in culture probably reflects the loss of most of the neuropilar processes when these neurons were cultured.

\section{Responses of $R z$ neurons to nicotine and nicotinic antagonists}

The results presented in Figures 3 and 5 show that ACh responses in the two different types of $\mathrm{Rz}$ neurons differed significantly in their ionic selectivity. It was therefore of interest to determine whether the receptors mediating the responses also had different ligand-recognition properties. In order to test for this possibility, we characterized the responses of $\mathrm{Rz}(5,6)$ and $\mathrm{Rz}(\mathrm{X})$ neurons to nicotinic agonists and antagonists.

Responses to nicotine. $\mathrm{Rz}(\mathrm{X})$ and $\mathrm{Rz}(5,6)$ neurons were tested
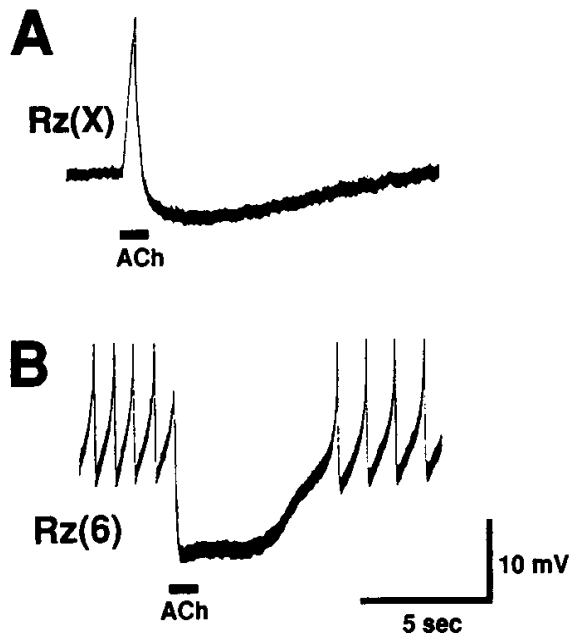

Figure 6. Cholinergic responses of $\mathrm{Rz}$ neuronal somata held in culture for $1 \mathrm{~d}$. The two traces are intracellular responses recorded from isolated somata of $\mathrm{Rz}(\mathrm{X})(A)$ and $\mathrm{Rz}(6)(B)$ to the application of $\mathrm{ACh}\left(10^{-3} \mathrm{M}\right.$ in the pipette). Responses were obtained from six neurons of each type, and they were essentially identical to those shown. with nicotine at a concentration of $1 \mathrm{~mm}$ in the micropipette (Fig. $7 A$ ). The response of $\mathrm{Rz}(\mathrm{X})$ neurons to nicotine consisted of the same three phases as seen in the response to ACh: a fast depolarizing phase, a hyperpolarization, and a delayed depolarization (compare Fig. $7 A$ to Fig. $4 A$ ). However, nicotine invariably produccd a much longer delayed depolarization than did ACh, probably because nicotine is not broken down by AChE. Nicotine, like ACh, hyperpolarized the R $7(5,6)$ neurons, but the response to nicotine was biphasic, a feature that was less obvious in responses to ACh (e.g., Fig. 4B). These results suggest that the responses of both $\mathrm{Rz}(\mathrm{X})$ and $\mathrm{Rz}(5,6)$ neurons depend on nicotinic ACh receptors.

Responses to nicotinic antagonists. To characterize the initial responses further, we determined the effects of two nicotinic antagonists, $\alpha$-Bgt and $d$-tubocurarine, on the two types of cells. In these experiments, $\mathrm{ACh}$ was applied to the somata of $\mathrm{Rz}$ neurons, in isolated ganglia or in culture, with $\alpha$-Bgt or $d$-tubocurarine present in the bathing solution. The initial depolarizing response in $\mathrm{Rz}(\mathrm{X})$ was blocked reversibly by $d$-tubocurarine at $10^{-4} \mathrm{M}$ (Fig. $7 \mathrm{~B}$ ), but was unaffected, or even slightly accentuated, by $\alpha$-Bgt at $10^{-7} \mathbf{M}$ (Fig. 7C). Conversely, the hyperpolarizing responsc of $\mathrm{Rz}(5,6)$ was blocked irreversibly by $\alpha$-Bgt (Fig. 7C), but was unaffected by $d$-tubocurarine at the same concentrations used on the $\mathrm{Rz}(\mathrm{X})$ neurons (Fig. $7 B$ ). Note that during and after the application of $\alpha$-Bgt, the $A C h$ responses of both kinds of $R z$ neuron were different from the control response. The depolarization in $\mathrm{Rz}(\mathrm{X})$ was larger, indicating that this neuron's hyperpolarizing response, not apparent as a distinct feature in the control record, was blocked by $\alpha$-Bgt. In addition, blocking the hyperpolarizing response of $\mathrm{Rz}(5,6)$ to ACh sometimes, as in the case shown in Figure $7 C$, uncovered a depolarizing component. When nicotine, rather than $\mathrm{ACh}$, was used as the agonist, $d$-tubocurarine and $\alpha$-Bgt had the same effects as they had on the $\mathrm{ACh}$ responses (data not shown). Thus, we conclude that both the depolarizing and hyperpolarizing responses are nicotinic in nature, and that these two antagonists distinguish between them. 

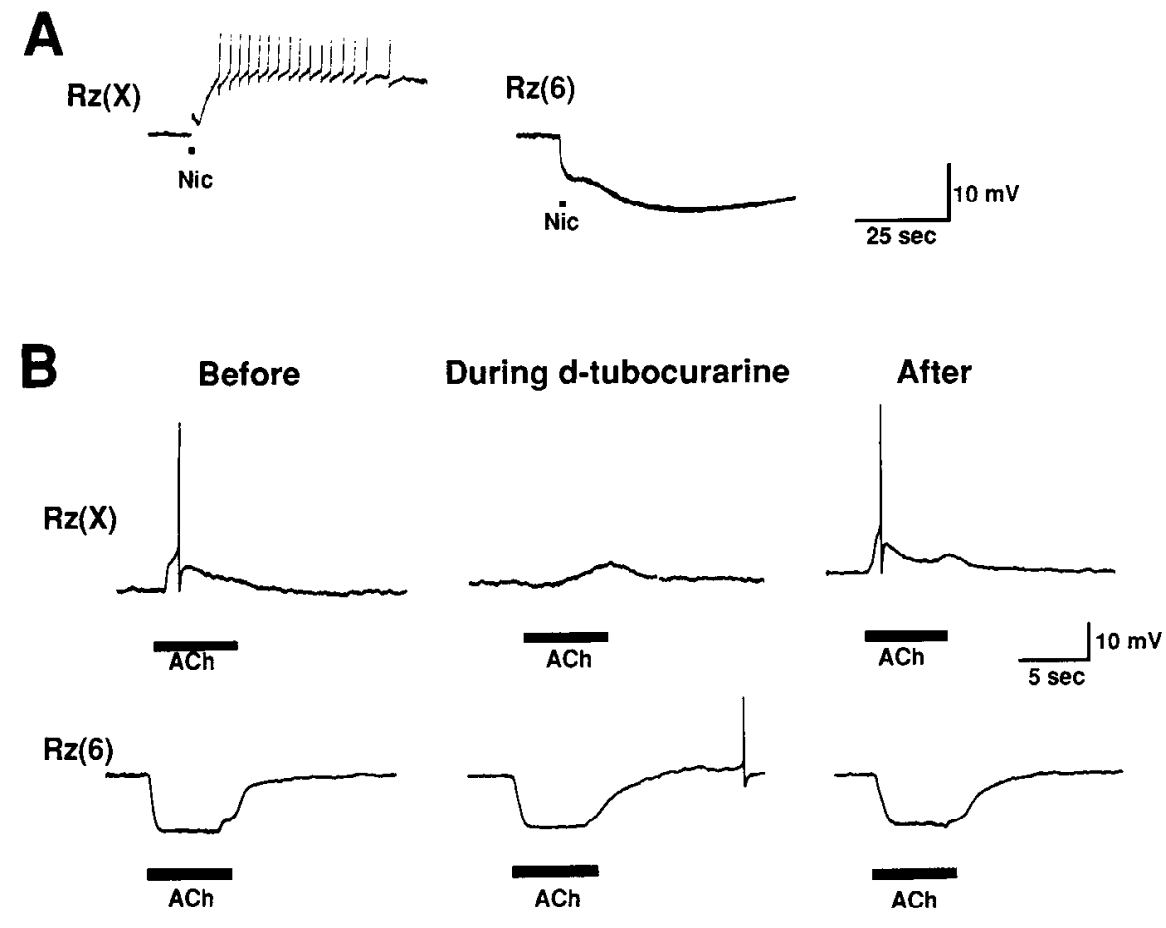

Figure 7. Evidence that the initial responses of $\mathrm{Rz}$ neurons to $\mathrm{ACh}$ are nicotinic. $A$, Responses of $\mathrm{Rz}$ neurons to nicotine. Nicotine $\left(10^{-3} \mathrm{M}\right.$ in the pipette) was applied to the somata of $\mathrm{Rz}(\mathrm{X})$ and $\mathrm{Rz}(6)$ neurons. The bars below the recordings indicate the onset and duration of the pulses. Cells were studied at their resting membrane potentials, which were -30 to $-45 \mathrm{mV}$. $B$. Effects of the nicotinic antagonist $d$-tubocurarine $\left(10^{-4} \mathrm{M}\right)$ on the responses of $\mathrm{Rz}(\mathrm{X})$ and $\mathrm{Rz}(6)$ to $\mathrm{ACh}$. The $d$-tubocurarine was applied in the bathing solution while recording the responses of the $\mathrm{Rz}$ neurons to the application of ACh $\left(10^{-3} \mathrm{M}\right.$ in the micropipette). The leftmost traces show the response of ACh hefore application of the antagonist, the middle traces are 60 sec after the application of the antagonist was begun, and the rightmost traces are $90 \mathrm{sec}$ after starting to wash out the antagonist. The block produced by $d$-tubocurarine was typically evident within $30 \mathrm{sec}$ and reversed within 30$60 \mathrm{sec}$ of washing. $C$, Effects of $\alpha$-Bgt, at $10^{-7} \mathrm{M}$, applied to the $\mathrm{Rz}$ neurons in the same manner. This antagonist needed to be applied for $10 \mathrm{~min}$ to block the hyperpolarizing response fully in $\mathrm{Rz}(5,6)$, and this effect could not be reversed even after $60 \mathrm{~min}$ of washing. All experiments were repeated in three to nine $\mathrm{Rz}$ neurons.

\section{Development of the $A C h R$ response}

$A C h$ responses in embryos. Using the same techniques to isolate and desheath ganglia that have been described for adult neurons, it was possible to determine how $\mathrm{Rz}$ neurons responded to $\mathrm{ACh}$ in embryos older than $19 \mathrm{~d}$. This stagc is about two-thirds of the way through embryogenesis (Fernandez and Stent, 1982). In these embryos, $\mathrm{Rz}$ neurons gave responses to $\mathrm{ACh}$ and to nicotine that were essentially identical to the responses of adult $\mathrm{Rz}$ neurons (Fig. 8). Furthermore, $d$-tubocurarine selectively blocked the fast depolarization in $\mathrm{Rz}(\mathrm{X})$, and $\alpha$-Bgt selectively blocked the hyperpolarizing response of $\mathrm{Rz}(5,6)$, as they did in adults. These results indicate that the distinction between the two types of $\mathrm{ACh}$ receptors arises during embryogenesis, and not as the result of later events, such as sexual maturation, which occurs nearly a year later (Sawyer, 1986).

Changing the $A C h$ responses of $R z(5,6)$ neurons by ablating the reproductive primordia. To determine whether the type of $\mathrm{ACh}$ receptor normally expressed by an $\mathrm{Rz}(5,6)$ neuron depends upon the presence of their target organs, the reproductive ducts, the embryonic reproductive ducts were removed during em-

bryonic day $10(\mathrm{E} 10)$, and the responses of $\mathrm{Rz}(5,6)$ to $\mathrm{ACh}$ were tested 2-3 weeks later. Ablating reproductive tissue before it can affect the development of $\mathrm{Rz}$ neurons presents a problem: if the reproductive tissues are ablated too early, the embryo produces new reproductive tissue; if the reproductive tissue is ablated too late, the $\mathrm{Rz}$ neurons may become committed irreversibly to their "reproductive" phenotype (e.g., smaller somata, fewer neuropilar branches, no processes in the interganglionic connectives, as determined by Loer et al., 1987). To determine whether we had removed the reproductive tissue during the appropriate developmental time window, we used two criteria.

(1) The presence of reproductive tissue: if reproductive tissue was present at the time of dissection, the ablation was deemed unsuccessful; that is, either the surgery had spared the reproductive tissue or new tissue had grown back. The $\mathrm{Rz}$ neurons in these segments consistently responded to $\mathrm{ACh}$ like normal $\mathrm{Rz}(5,6)$ neurons.

(2) The size of the Rz somata: an unsuccessful ablation should leave the area of an $\mathrm{Rz}(5,6)$ soma at about $37 \%$ of the area of $\mathrm{Rz}(\mathrm{X})$ neurons in the same nerve cord, whereas a successful 


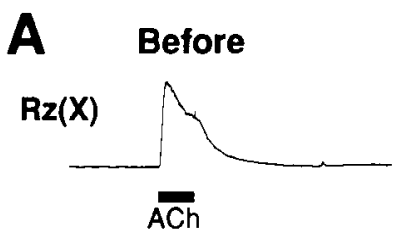

Figure 8. ACh responses of embryonic $\mathrm{Rz}$ neurons. $A$, The effect of $d$-tubocurarine on the ACh response of an $\mathrm{Rz}(12)$ neuron from an embryo on E20. $B$, The effect of $\alpha$-Bgt on the ACh response of an $\operatorname{Rz}(6)$ neuron from an embryo on E20. As in adult $\mathrm{Rz}$ neurons, $d$-tubocurarine had no effect on $\operatorname{Rz}(5,6)$ neurons, nor did $\alpha$-Bgt block the depolarizing responses of $\mathrm{Rz}(\mathrm{X})$ neurons (data not shown).

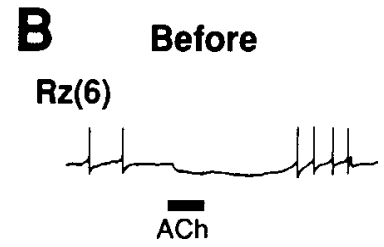

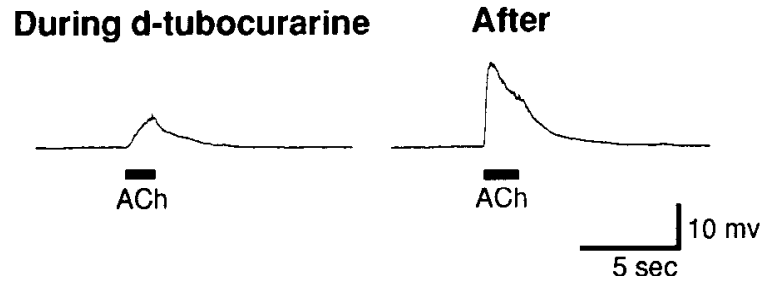

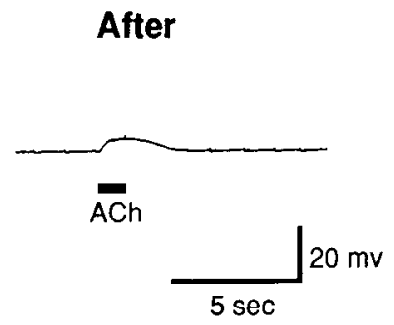

ablation would move the size nearer to that of $\mathrm{Rz}(\mathrm{X})$ (Loer et al., 1987).

Of $14 \mathrm{Rz}(5,6)$ neurons tested in seven juvenile leeches following ablations, nine retained their normal, hyperpolarizing response to $\mathrm{ACh}$ whereas five others produced an $\mathrm{Rz}(\mathrm{X})$-like depolarization to ACh (Table 2). The $\operatorname{Rz}(5,6)$ neurons that depolarized to ACh also had significantly larger somata $[62.3 \pm$ $2.8 \%$ of the cross-sectional area of $\mathrm{Rz}(\mathrm{X})$ neurons in the same nerve cords] than did the $\mathrm{Rz}(5,6)$ neurons that hyperpolarized in response to $\mathrm{ACh}$. Their somatic area was $39.9 \pm 3.3 \%$ of the $\mathrm{Rz}(\mathrm{X})$ somatic area. $\mathrm{Rz}(5,6)$ somata in untreated embryos at these ages have somata that are, on the avcragc, $37.2 \%$ of the area of $\mathrm{Rz}(\mathrm{X})$ neurons (Jellies et al., 1987). From the present results, we conclude that ablating the embryonic reproductive ducts can modify the type of functional $\mathrm{ACh}$ receptor expressed by an $\operatorname{Rz}(5,6)$ neuron, and that this change is accompanied by morphological modifications, in this case, somatic size.

\section{Discussion}

\section{Responses of $R z$ neurons to neurotransmitters}

In this study, $\mathrm{Rz}(\mathrm{X})$ neurons responded to focally applied neurotransmitters in much the same way that $\mathrm{Rz}$ neurons from unspecified locations had responded to bath-applied transmitters in previous studies: glutamate and ACh depolarized the $\mathrm{Rz}$ neurons, whereas 5-HT, strychnine, and octopamine hyperpolarized them (Leake and Walker, 1980; Gardner and Walker, 1983). GABA, which had been shown to be an inhibitory transmitter onto other ncurons in the lecch (Cline, 1986), had no effect on $\mathrm{Rz}$ neurons. In general, $\mathrm{Rz}(5,6)$ neurons responded to these substances in qualitatively the same way as $\operatorname{did} \mathrm{Rz}(\mathrm{X})$;

Table 2. Properties of $R z(5,6)$ neurons after reproductive primordia were ablated on E10

\begin{tabular}{lcr} 
& \multicolumn{2}{c}{ Response to ACh } \\
\cline { 2 - 3 } Cell type & D & H \\
\hline $\operatorname{Rz}(5,6)$, ablation on $\mathrm{E} 10$ & 5 & 9 \\
$\operatorname{Rz}(5,6)$, no ablations & 0 & 11 \\
$\operatorname{Rz}(\mathrm{X})$ & 16 & 1
\end{tabular}

All recordings were made from exposed $\mathrm{Rz}$ neurons in ganglia obtained from animals $20-34 \mathrm{~d}$ after the ablations, when the animals were juveniles. All abbreviations are as defined for Table 1.

the one exception was their response to ACh. Although all $\mathrm{Rz}$ neurons responded in a complex way to $\mathrm{ACh}$, the initial responses distinguished clearly between the two cell types: $R \nless(X)$ neurons initially depolarized and $\mathrm{Rz}(5,6)$ neurons hyperpolarized. Therefore, we further characterized these initial responses to $\mathrm{ACh}$, both physiologically and pharmacologically, and determined that the different responses are developmentally regulated, stable features of the two $\mathrm{Rz}$ neuronal phenotypes.

\section{Multiple types of cholinergic responses on segmentally specific $R z$ neurons}

The complexity of $\mathrm{Rz}$ neurons' response to $\mathrm{ACh}$ is not surprising, because multiple types of nicotinic receptors have been reported on other invertebrate neurons (Kehoe, 1972; Gerschenfeld, 1973; Leake and Walker, 1980; Gardner and Walker, 1983; Zufall et al., 1988; Pfeiffer-Linn and Glantz, 1989; Trimmer and Weeks, 1989; Waldrop and Hildebrand, 1989) and glial cells (Ballanyi and Schlue, 1989). For instance, particular identified neurons from Aplysia have three different responses to ACh: an $\mathrm{Na}^{+}$-dependent depolarization that is blocked by $d$-tubocurarine, hexamethonium, and atropine, but not by $\alpha$-Bgt; a fast $\mathrm{Cl}^{-}$-dependent hyperpolarization blocked by both $d$-tubocurarine and $\alpha$-Bgt; and a slow $\mathrm{K}^{+}$-dependent hyperpolarization resistant to both $d$-tubocurarine and $\alpha$-Bgt (Kehoe, 1972; Kehoe et al., 1976). Other molluscan neurons have a depolarizing response to ACh that is blocked by $d$-tubocurarine, $\alpha$-Bgt, hexamethonium, and atropine (Leake and Walker, 1980). Also, a pair of leech neurons, the $\Lambda \mathrm{P}$ cells, are hyperpolarized by $\mathrm{ACh}$. This response has been studied in cultured cells and was found to be mediated by $\mathrm{Cl}^{-}$and blocked by both $\alpha$-Bgt and $d$-tubocurarine (Pellegrino and Simonneau, 1984). More recently, hyperpolarizing responses thought to be nicotinic have been reported on neurons within the rat CNS (de la Garza et al., 1987; Wong and Gallagher, 1989).

In contrast with these unusual $\mathrm{ACh}$ responses, the fast depolarizing response of $\mathrm{Rz}(\mathrm{X})$ neurons to $\mathrm{ACh}$ appears to be similar to typical nicotinic responses of vertebrate neurons (Lipton et al., 1987; Mulle et al., 1991): it is elicited by nicotine, it is blocked by $d$-tubocurarine, but not by $\alpha$-Bgt, and it is mediated by channels whose reversal potential suggests that they are permeable to more than one cation. On the other hand, the fast hyperpolarizing response of $\operatorname{Rz}(5,6)$ is somewhat unusual: although it is activated by nicotine, it is blocked by $\alpha$-Bgt, but 
not by $d$-tubocurarine, and it is mediated by channels that select for $\mathrm{Cl}^{-}$. In recent years, the molecular nature of many subunits comprising nicotinic $\mathrm{ACh}$ receptors has been determined (Noda et al., 1982; Boulter et al., 1986; Steinbach and Ifune, 1989; Changeux et al., 1990; Role, 1992). To date all nicotinic receptors whose subunits have been sequenced produce depolarizing responses, probably because of a preponderance of negatively charged amino acid residues found near particular membranespanning regions (Unwin, 1989). It appears that neuronal $\alpha$-subunits bind both agonists and $\alpha$-Bgt (Steinbach and Ifune, 1989), but some details of channel properties (Papke et al., 1989) and the receptors' pharmacological properties (Luetje and Patrick, $1991)$ are also influenced by $\beta$-subunits that combine with $\alpha$-subunits to produce functional receptors. Knowing the sequences of the ACh subunits in leech $\mathrm{Rz}$ neurons (French et al., 1990) may contribute to understanding which segments of $\mathrm{ACh}$ receptor subunits are responsible for differences in ionic selectivity (Figs. 3, 5) and may suggest what determines the differential sensitivity of these receptors to $d$-tubocurarine and $\alpha$-Bgt (Figs. 7, 8).

Several observations suggest that the slower $\mathrm{ACh}$ responses of $\mathrm{Rz}$ neurons are quite different from the initial, fast responses. For instance, the fast depolarization of $\mathrm{Rz}(\mathrm{X})$ neurons desensitizes after only a few repeated pulses of $\mathrm{ACh}$, while the slow depolarization remains the same amplitude (Fig. 4). It is possible that these slower responses are more like vertebrate muscarinic responses, and we have begun to explore the response of $\mathrm{Rz}(\mathrm{X})$ and $R z(5,6)$ neurons to agonists and antagonists of vertebrate muscarinic ACh receptors (Szczupak et al., 1992).

The biological function of these ACh responses in $\mathrm{Rz}$ neurons is not obvious. The cholinergic responses described in this article must, with the exception of the prolonged depolarization in $\mathrm{Rz}(\mathrm{X})$, be mediated by receptors present in the soma of the cell, because they persist when the cell body is severed from its processes and placed into culture (Fig. 6). Axosomatic contacts are thought to be rare in leeches (French and Muller, 1986), and it has yet to be resolved whether these receptors are the same as $\mathrm{ACh}$ receptors found in the postsynaptic membrane of these neurons, which is located on processes within the neuropil. It is possible, for example, that the somatic receptors are identical with those found in the processes, but that they have been inserted into somatic membrane and are secondarily transported along the processes. Alternatively, these receptors may mediate a response in which $\mathrm{ACh}$ functions more like a hormone, a role that has been proposed for nonsynaptic ACh receptors in other invertebrates (Sargent et al., 1977; Marder, 1987). Finally, the sourcc of the ACh that might bind to these receptors in situ is unknown. To date, the only neurons in leech ganglia that are known to be cholinergic are the motor neurons and some otherwise unidentified neurons that send axons into the periphery (Wallace, 1981), and none of these have been found to make synaptic contact with $\mathrm{Rz}$ neurons.

\section{Development of differences in responses to $A C h$}

The different responses of $\mathrm{Rz}(5,6)$ and $\mathrm{Rz}(\mathrm{X})$ to $\mathrm{ACh}$ represent yet another property in a growing list of anatomical (Glover and Mason, 1986; Loer et al., 1987) and physiological (Loer and Kristan, 1989c; Wittenberg et al., 1990) characteristics that distinguish between the two cell types. In addition, the data in Table 2 indicate that, like the previously described features, the nature of the $\mathrm{ACh}$ response of $\mathrm{Rz}(5,6)$ neurons develops normally only when the reproductive ducts are present in segments
5 and 6 . Ablating the embryonic reproductive ducts can cause these neurons to develop a depolarizing response to $\mathrm{ACh}$. In future studies, the distinctive hyperpolarization that is normally present in $\mathrm{Rz}(5,6)$ should prove to be a useful cell-specific marker of the $\mathrm{Rz}(5,6)$ phenotype, while the distinctive fast depolarization that is normally present in $\mathrm{Rz}(\mathrm{X})$ should mark the $\mathrm{Rz}(\mathrm{X})$ phenotype. Both responses can be used to assay the phenotype of neurons that have been removed from their normal environment and placed in culture with different potential target tissues (French et al., 1991).

ACh receptors have been shown to be developmentally regulated in several systems. For example, some vertebrate muscles express different types of $\mathrm{ACh}$ receptors during different phases of normal embryonic development (Schuetze and Role, 1987), and different types of $\mathrm{ACh}$ receptors are expressed on vertebrate neurons during embryogenesis (Baldwin et al., 1988; Margiotta and Gurantz, 1989; Moss et al., 1989; Jacob, 1991). Neither the nature of the signal controlling $\mathrm{ACh}$ receptor expression nor the mechanism of regulation is known for any system. Identifying ACh receptor subunits expressed in the leech (French et al., 1990), particularly the two different types that mediate the initial phase of the ACh response in each of the $\mathrm{Rz}$ neuron types, will help us to resolve how these important molecules are regulated in leech neurons.

\section{References}

Baldwin TJ, Yoshihara CM, Blackmer K, Kintner CR, Burden J (1988) Regulation of acetylcholine receptor transcript expression during development in Xenopus laevis. J Cell Biol 106:469-478.

Ballanyi K, Schlue WR (1989) Electrophysiological characterization of a nicotinic acetylcholine receptor on leech neuropile glial cells. Glia $2: 330-345$.

Boulter JK, Evans K, Goldman D, Martin G, Treco D, Heinemann S, Patrick J (1986) Isolation of a cDNA clone coding for a possible neural nicotinic acetylcholine receptor $\alpha$-subunit. Nature 319:368374.

Changeux JP, Benoit P, Bessis A, Cartaud J, Devillers-Thiery A, Fontaine B, Galzi JL, Klarsfeld A, Laufer R, Mulle C (1990) The acetylcholine receptor: functional architecture and regulation. Adv Second Messenger Phosphoprotein Res 24:15-19.

Cline HP (1986) Evidence for GABA as a neurotransmitter in the leech. J Neurosci 6:2848-2856.

Corey DP, Stevens CF (1983) Science and technology of patch-recording electrodes. In: Single-channel recordings (Sakmann B, Neher E, eds), pp 53-68. New York: Plenum.

de la Garza R, McGuire TJ, Freedman R, Hoffer BJ (1987) Selective antagonism of nicotine actions in the rat cerebellum with $\alpha$-bungarotoxin. Neuroscience 23:887-891.

Dietzel ID, Drapeau P, Nicholls JG (1986) Voltage dependence of 5-hydroxytryptamine release at a synapse between identified leech neurones in culture. J Physiol (Lond) 372:191-205.

Doe CQ, Goodman CS (1985) Early events in insect neurogenesis. II. The role of cell interactions and cell lineage in the determination of neuronal precursor cells. Dev Biol 111:206-219.

Drapeau P, Melinyshyn E, Sanchez-Armass S (1989) Contact-mediated loss of the nonsynaptic response to transmitter during reinnervation of an identified leech neuron in culture. J Neurosci 9:25022508.

Fernandez J, Stent GS (1982) Embryonic development of the hirudinid leech Hirudo medicinalis: structure, development and segmentation of the germinal plate. J Embryol Exp Morphol 72:71-96.

French K, Kristan W Jr (1992) Intrinsic and extrinsic factors influencing the development of Retzius neurons in the leech nervous system. In: Determinants of neuronal identity (Shankland M, Macagno E, eds), pp 97-117. San Diego: Academic.

French K, Jordan S, Szczupak L, Kristan W Jr (1991) Properties of Hirudo Retzius neurons cultured in isolation and with reproductive ducts. Soc Neurosci Abstr 17:534.

French KA, Muller KJ (1986) Regeneration of a distinctive set of 
axosomatic contacts in the lecch central nervous systcm. J Neurosei $6: 318-324$.

French KA, Reynolds SA, Hartley M, Heinemann S, Kristan WB Jr (1990) Multiple acetylcholine genes are expressed in a tissue-specific fashion in the leech, Hirudo. Soc Neurosci Abstr 16:974.

French KA, Jordan SM, Loer CM, Kristan WB Jr (1992) Mesenchyme of embryonic reproductive ducts directs the process outgrowth of Retzius neurons in the medicinal leech. Dev Biol 153:122-140.

Gardner CR, Walker RJ (1983) The roles of putative neurotransmitters and neuromodulators in annelids and related invertebrates. Prog Neurobiol 18:81-120.

Gerschenfeld HM (1973) Chemical transmission in invertebrate central nervous systems and neuromuscular junctions. Physiol Rev 53: $1-119$.

Gleizer L, Stent GS (1990) Control of segment identity in the lecch embryo. Soc Neurosci Abstr 16:650.

Glover JC, Mason A (1986) Morphogenesis of an identified leech neuron: segmental specification of axonal outgrowth. Dev Biol 115: 256-260.

Jacob MH (1991) Acetylcholine receptor expression in developing chick ciliary ganglion cells. J Neurosci 11:1701-1712.

James VA, Walker RJ, Wheal HV (1980) Structure-activity studies on an excitatory receptor for glutamate on leech Retzius neurones. Br J Pharmacol 68:711-717.

Jellies J, Loer CM, Kristan WB Jr (1987) Morphological changes in leech Retzius neurons after target contact during embryogenesis. J Neurosci 7:2618-2629.

Kehoe J (1972) Ionic mechanisms of a two-component cholinergic inhibition in Aplysia neurones. J Physiol (Lond) 225:85-1 14.

Kehoe JS, Sealock R, Bon C (1976) Effects of $\alpha$-toxins from Bungarus multicinctus and $B$. caeruleus on cholinergic responses in Aplysia neurones. Brain Res 107:527-540.

Kristan WB Jr, French KA (1988) Segment-specific differences in ACh receptors on leech $\mathrm{Rz}$ neurons. Soc Neurosci Abstr 14:164.

Leake LD, Walker RJ (1980) Invertebrate neuropharmacology. New York: Wiley.

LeDouarin NM (1980) Migration and differentiation of neural crest cells. Curr Top Dev Biol 16:31-85.

Lent, CM (1973) Retzius cells: neuroeffectors controlling mucus release by the leech. Science 179:693-696.

Letourneau PC, Kater SB, Macagno ER (1991) The nerve growth cone. New York: Raven.

Lipton SA, Aizenman E, Loring RH (1987) Neural nicotinic acetylcholine responses in solitary mammalian retinal ganglion cells. Pfluegers Arch 410:37-43.

Loer CM, Kristan WB Jr (1989a) Peripheral target choice by homologous neurons during embryogenesis of the medicinal leech. I. Segment-specific preferences of Retzius cells. J Neurosci 9:513-527.

Loer CM, Kristan WB Jr (1989b) Peripheral target choice by homologous neurons during embryogenesis of the medicinal leech. II. Innervation of ectopic reproductive tissue by nonreproductive Retzius cells. J Neurosci 9:528-538.

Loer CM, Kristan WB Jr (1989c) Central synaptic inputs to identified leech neurons determined by peripheral targets. Science 244:64-70.

Loer CM, Jellies J, Kristan WB Jr (1987) Segment-specific morphogenesis of leech Retzius neurons requires particular peripheral targets. J Neurosci 7:2630-2638.

Luetje CW, Patrick J (1991) Both alpha- and beta-subunits contribute to the agonist sensitivity of neuronal nicotinic acetylcholine receptors. J Neurosci 11:837-845.

Macagno ER, Peinado A, Stewart RR (1986) Segmental differentiation in the leech nervous system: specific phenotypic changes associated with ectopic targets. Proc Natl Acad Sci USA 83:2746-2750.

Marder E (1987) Neurotransmitters and neuromodulators. In: The crustacean stomatogastric system (Selverston AI, Moulins M, eds), pp 263-300. New York: Springer.

Margiotta JF, Gurantz D (1989) Changes in the number, function and regulation of nicotinic acetylcholine receptors during neuronal development. Dev Biol 135:326-339.

Mat Jais AM, Kerkut GA, Walker RJ (1983) The ionic mechanism associated with the biphasic glutamate response on leech Retzius cells. Comp Biochem Physiol [C] 74:425-432.

Moss BL, Schuetze SM, Role LW (1989) Functional properties and developmental regulation of nicotinic acetylcholine receptors on embryonic chicken sympathetic neurons. Neuron 3:597-607.
Mulle C, Vidal C, Benoit P, Changeux J-P (1991) Existence of different subtypes of nicotinic acetylcholine receptors in the rat habenulo-interpeduncular system. J Neurosci 11:2588-2597.

Nicholls JG, Baylor DA (1968) Specific modalities and receptive fields of sensory neurons in the CNS of the leech. J Neurophysiol 31:740756.

Nicholls JG, Purves D (1970) A comparison of chemical and electrical synaptic transmission between single sensory cells and a motoneurone in the central nervous system of the leech. J Physiol (Lond) 225:637656.

Noda M, Takahashi H, Tanabe T, Toyosato M, Furutani Y, Hirose T, Asai M, Inayama S, Miyata T, Numa S (1982) Primary structure of the $\alpha$-subunit precursor of Torpedo californica acetylcholine receptor deduced from cDNA sequence. Nature 299:793-797.

Papke R, Boulter J, Patrick J, Heinemann S (1989) Single-channel currents of rat neuronal nicotinic acetylcholine receptors expressed in Xenopus oocytes. Neuron 3:589-596.

Patterson PH, Chun LLY (1977) The induction of acetylcholine synthesis in primary cultures of dissociated rat sympathetic neurons. I. Effects of conditioned medium. Dev Biol 56:263-280.

Pellegrino M, Simmoneau M (1984) Distribution of receptors for acetylcholine and 5-hydroxytryptamine on identified leech neurones growing in culture. J Physiol (Lond) 352:669-684.

Perris R, Bronner-Fraser M (1989) Recent advances in defining the role of the extracellular matrix in neural crest development. Comments Dev Neurobiol 1:61-83.

Pfeiffer-Linn C, Glantz RM (1989) Acetylcholine and GABA mediate opposing actions on neuronal chloride channels in crayfish. Science 245:1249-1251.

Potter DD, Landis SC, Matsumoto SG, Furshpan EJ (1986) Synaptic functions in rat sympathetic neurons in microcultures. II. Adrenergic/ cholinergic dual status and plasticity. J Neurosci 6:1080-1090.

Role LW (1992) Diversity in primary structure and function of neuronal nicotinic acetylcholine receptors. Curr Opin Neurobiol 2:254 262.

Sargent PB, Yau K-Y, Nicholls JG (1977) Extrasynaptic receptors on cell bodies of neurons in the central nervous system of the leech. J Neurophysiol 40:446-452.

Sawyer RT (1986) Leech biology and behaviour, Vol 1. Oxford: Clarendon.

Schotzinger RJ, Landis SC (1990) Acquisition of cholinergic and peptidergic properties by sympathetic innervation of rat sweat glands requires interaction with normal target. Neuron 5:91-100.

Schuetze SM, Role LW (1987) Developmental regulation of nicotinic acetylcholine receptors. Annu Rev Neurobiol 10:403-457.

Shankland SM, Macagno ER (1992) Determinants of neuronal identity. San Diego: Academic.

Smith CL, Frank E (1987) Peripheral specification of sensory neurons transplanted to novel locations along the neuraxis. J Neurosci 7:15371549.

Smith PA, Walker RJ (1975) Further studies on the action of various 5-hydroxytryptamine agonists and antagonists on the receptors of neurones from the leeches, Hirudo medicinalis and Haemopis sanguisuga. Comp Biochem Physiol [C] 51:195-203.

Steinbach JH, Ifune C (1989) How many kinds of nicotinic acetylcholine receptors are there? Trends Neurosci 12:3-6.

Sunderland AJ, Leake LD, Walker RJ (1980) Evidence for an amine receptor on the Retzius cells of the leeches Hirudo medicinalis and Haemopis sanguisuga. Comp Biochem Physiol [C] 67:159-166.

Szczupak L, Jordan S, French KA, Kristan WB Jr (1992) Segmentspecific acetylcholine responses of Retzius neurons in the medicinal leech. Soc Neurosci Abstr 18:1471.

Trimmer BA, Weeks JC (1989) Effects of nicotinic and muscarinic agents on an identified motoneurone and its direct afferent inputs in larval Manduca sexta. J Exp Biol 144:303-337.

Unwin N (1989) The structure of ion channels in membranes of excitable cells. Neuron 3:665-676.

Waldrop B, Hildebrand JG (1989) Physiology and pharmacology of acetylcholinergic responses of interneurons in the antennal lobes of the moth Manduca sexta. J Comp Physiol 164:433-441.

Walker RJ, Smith PA (1973) The ionic mechanisms for 5-HT inhibition on Retzius cells of the leech Hirudo medicinalis. Comp Biochem Physiol [A] 45:979-994.

Wallace BG (1981) Neurotransmitter chemistry. In: Neurobiology of 
the leech (Muller KJ, Nicholls JG, Stent GS, eds), pp 147-172. Cold Spring Harbor, NY: Cold Spring Harbor Laboratory.

Wittenberg G, Loer CM, Adamo SA, Kristan WB Jr (1990) Segmental specialization of neuronal connectivity in the medicinal leech. J Comp Physiol 167:453-459.
Wong LA, Gallagher JP (1989) A direct receptor-mediated inhibition recorded intracellularly in vitro. Nature 341:439-442.

Zufall F, Franke C, Hatt H (1988) Acetylcholine activates a chloride channel as well as glutamate and GABA. J Comp Physiol [A] 163: $609-620$. 